\title{
A Swan Uncarved: Russian and Irish Heroes BREAKING THE TABLE ETIQUETTE ${ }^{1}$
}

\section{Nina CheKhonadskaya}

\section{Introduction: definition and classifications of feasts}

Quarrels at feasts were a common topic in heroic poetry and epic in the literatures of many countries throughout the ages. The feast was a convenient occasion for a public display of one's status and wealth and a handy opportunity for the re-establishment and re-evaluation of one's public role.

In the last few decades, the concept of 'feast' has attracted much attention from historians, archaeologists and ethnologists, and the evidence concerning the subject has been discussed and analysed in a variety of ways, including social and gender prospectives. Different theories concerning the meaning of feasting in different ages and cultures have been put forward.

The definition of what constitutes a feast is a moot point. Among the leading scholars in the field, B. Hayden (Hayden 2001: 28) prefers a very broad definition:

A feast is any sharing between two or more people of special foods (i.e. foods not generally served at daily meals) in a meal for a special purpose or occasion.

M.J. Clarke (Clarke 2001: 145) gives a similar description:

A feast is any ritualised meal that is consumed by two or more people. By 'ritualised', I mean that the meal is not eaten solely for sustenance, but rather, is considered as only one facet of a greater social event.

M. Dietler (Dietler 1996: 89) considers the social function of feasting more important:

As public ritual events, in contrast to daily activity, feasts provide an arena for the highly condensed symbolic representation of social relations. Like all rituals, they express an idealised concept that is the way people believe relations exist or should exist rather than how they are necessarily manifested in daily activity. However, in addition to this idealised representation of the social order, they also offer the potential for

\footnotetext{
I thank Prof. Dr. K. H. Schmidt and Prof. Dr. H. L. C. Tristram for their suggestions expressed at the conference. I am also indebted to Dr. A. L. Barkova for a number of helpful hints regarding the Russian side of the question. However, they are not to be held responsible for the views expressed in this paper. All translations are mine unless otherwise noted.
} 
manipulation by individuals or groups attempting to alter or make statements about their relative position within that social order as it is perceived and presented.

These opportunities to make a 'statement' could naturally lead to boasting, mutual insults and quarrels. As S. N. Tranter (Tranter 1992: 157) puts it in his article on marriage feasts in Old Iceland:

A jest over the beer turns to bitter earnest, or the close proximity of once feuding partners places an unendurable strain on a truce reached only after the greatest of efforts by the mediators and feud breaks out afresh. But to these general dangers comes that specific to the marriage that family position and politics are at stake.

The last point, however, holds good not only for the marriage feast. Family position and politics would always be at stake where people from more than two families or two political units are present.

Different classifications of feasts have been suggested and the actual purpose of the feast is the least significant among them ("the kinds of pretexts that might be used for holding feasts are only constrained by human creativity" (Hayden 2001: 37)). Since we are studying quarrels, we can classify feasts on the basis of how order is maintained at them. In this case, the feasts can be divided into the following categories:

a) regulated;

b) relatively regulated;

c) non-regulated.

By a regulated feast we mean one which has a universally recognised leader or host who can distribute food, or order it to be served, and whose propositions the guests should follow.

A relatively regulated feast is one where the master of ceremonies, an arbiter bibendi, is chosen from the audience on account of his/her age, fortune or authority (it is not necessarily the host). His orders may not always be followed. A random example is a feast in Sturlunga Saga, where the most prominent chieftain is given this position of authority at marriage feast and fulfils his obligations with relative success (Tranter 1992: 162-163).

A non-regulated feast is one where all guests are on an equal footing. There is no obvious leader and no reason can be produced for choosing one person to maintain order. A marriage feast, as it has been mentioned above, is especially dangerous, not because politics and status are at play, but because 
in many cases both parties are to be considered as equal and attempts at regulation are not forthcoming. Such a situation may also arise when the host is less powerful and important than the guests, as in Scéla Mucce meic Dathó.

\section{Feasts in medieval Irish tales and in Slavonic epic songs}

A number of Irish tales contain the theme of a quarrel at a feast. Among the most important texts are Scéla Mucce meic Dathó (SMMD) and the Fled Bricrend $(F B)$. The carving of the pig in $S M M D$ is the crucial point of the tale. The fact that the pig is left uncarved and the Ulster hero Conall Cernach eventually consumes most of its meat leads to a bloody fight. The relative standing of the two tribes - the Ulaid and the Connachta - depends on the distribution of meat which, in fact, does not take place because of the absence or/and the improper behaviour of the pig's owner.

Some Russian epic songs - bylinas - describing quarrels at feasts offer some interesting and enlightening parallels to $S M M D$. The main course is not a pig, but a swan - a traditional Russian specialty. ${ }^{2}$

Unlike most European epics, for all practical purposes Slavonic epic songs never existed as literary adaptations, but were recorded by scholars in the nineteenth and twentieth centuries from people who sometimes could not read or write. There are a number of written records of Russian epic from the seventeenth and eighteenth centuries, ${ }^{3}$ but even then, in some of the cases, the texts in question are believed to represent an oral performance written down on the spot.

The word bylina serves as a general term for Russian epic tales and means something like "a true story", "a story that really happened". This term was actually coined by some nineteenth-century scholars and was not in general use among the singers of tales themselves who would prefer to describe their songs as 'old stories' (starina $)^{4}$. In the seventeenth- and eighteenthcentury MSS mentioned above, they are sometimes referred to as 'tales' (skazaniye), 'histories' (istoriya), and 'stories' (povest'). ${ }^{5}$

2 Lipets 1969 is a special study of feasts in the bylinas, but mostly from the historical point of view, being an attempt to find the features of the tenth-thirteenth-century everyday life in the epic.

3 Most of them are edited in Astakhova 1960.

4 As the ending of many bylinas runs: A то старина, то и деянье 'This is the ancient story, this is the heroic deed'.

5 For a history of the term bylina and a very detailed introduction to nineteenth-century scholarship, see Loboda 1896. A review of publications up to the 1920s can be found in Skaftymov 1994 (1924). Further developments are followed in a useful series of pamphlets by Anikin 1978-1980. A general review, popular and well-illustrated (however, not impartial), is Kalugin 1989. 
The eating of an uncarved dish at a feast is represented in a number of bylinas. The plot and characters may differ, although some of those different stories are believed to have a common source (see below). But at the same time we can always discern a common pattern.

The person who can swallow the uncarved swan (sometimes a bull) is represented as a stranger and eventually an enemy. His rudeness, bad manners, and foreignness are strongly emphasised. The fact that the swan (and often a loaf of bread) is left uncarved is sometimes ascribed merely to the guest's gluttony, but sometimes also to foul play: the hostess is the stranger's lover and intentionally tries to avoid distributing proper portions. As a result, the stranger swallows the whole swan (often accompanied by a loaf and a vat of wine). This gluttony becomes the subject for open derision: the hero compares the stranger with an old mare (cow) or/and an old dog who died from gluttony. In the ensuing fight the stranger is defeated and killed.

This plot is represented in two tales, existing in a number of variants, mainly in a poetic form, recorded from an oral performance by storytellers in the nineteenth-twentieth centuries, although there are also some oral prose versions and some written prose and poetic versions. In the discussion which follows, it has not been possible to take all existing variants into consideration.

\section{The bylina about Alyosha Popovich and Tugarin $\mathrm{Zmeyevich}$}

The version most relevant for our purpose is the story ${ }^{6}$ usually entitled "Alyosha Popovich [Alyosha the priest's son] and Tugarin Zmeyevich [Tugarin the He-Snake's son]"7. The real historical persons may have served as prototypes for the characters in the story. Tugarin is identified with the Polovetz Khan Tugorkhan, killed in 1096. ${ }^{8}$ The Princess Apraksa is the Princess Eupraxia, who returned to Russia after the scandalous break-up and divorce from her husband, the Emperor of the Holy Roman

\footnotetext{
6 A list of versions can be found in DN \& AP: 397. A review of scholarship on this piece see in Propp 1958: 577-578. A geographical map showing distribution of this story among storytellers in different parts of Russia see in DN \& AP: 191.

7 In Russian (and Slavic) epic and fairytales the word zmej/zmij 'he-snake' is often used. The normal Russian term for a snake is zmeya 'she-snake'.

8 The etymology of the name Tugarin is doubtful. Some scholars are ready to identify Tugarin with the historical Khan, whose name is probably connected with the ethnonym "Tocharian". Others point to the Russian personal name "Tugarin", recorded in medieval sources. In this case it can be regarded as an apothropaic name connected with Russ. tuga 'sorrow, grief'. This would make Tugarin a synonym for an "enemy", the one whose forays and plunders bring sorrow and grief, see Kondrat'yeva 1967: 150-151.
} 
Empire Henry IV, a few years after Tugorkhan's demise. The prototype of Alyosha is a real thirteenth-century warrior Alexandr Popovich. Some of his deeds, and his death in 1223, are reported by contemporary annals. ${ }^{9}$ The story, as it seems, was not widely known among the storytellers: about 40 versions are recorded so far.

The story consists of three episodes:

a) Alyosha's departure from home (city of Rostov) with his servant;

b) The conflict with Tugarin at Prince Vladimir's feast in Kiev;

c) The duel with Tugarin, who rides on a winged horse.

The sequence of the pieces can change and they can double (as in the most well known version from the Kirsha Danilov's collection); sometimes a bylina consists of only one part (either the departure and the feast, or the feast and the duel, or the duel only, or the departure only). Perhaps B.M. Sokolov was right in supposing that originally there were three independent stories (Sokolov 1916: 17-19), see below.

The feast in this bylina takes place at the court of Prince Vladimir of Kiev. As an example we shall quote Kirsha Danilov's version. Being one of the earliest records (eighteenth-century),${ }^{10}$ this version, is, however, regarded as late in terms of structure, with its doubling of the episodes, probably combining features from different bylinas: ${ }^{11}$

И принесли лебёдушку белую, And they've brought in the white swan

И тут рушала княгиня лебедь белую, And the princess was cutting the white swan

Обрезала рученьку левую,

And she had cut her left hand.

Завернула рукавцом, под стол опустила,

She had enveloped her hand in the sleeve, under the table she put her hand

Говорила таково слово:

And these were the words she said:

“Гой вы еси, княгини-боярыни,

"Oh you my dear Princesses and Boyar ladies!

Либо мне резать лебедь белова,

Either I cut the white swan

A detailed study of the bylina and the historical Alyosha is Dashkevich 1883. Further references and a useful prosopography can be found in Kalugin 1989.

${ }_{10}$ The oldest record is a seventeenth century page with a fragment of this bylina, found in a family archive and published in 1894 (Astakhova 1960: № 27).

${ }^{11}$ All excerpts are quoted with the orthography and punctuation of the original (most records reflect a dialect pronunciation). 
Либо смотреть на мил живот,

На молода Тугарина Змеевича".

Он взявши, Тугарин, лебедь белую,

Всю вдруг проглатил,

Еще тут же ковригу монастырскую.

Говорит Алёша на полатном брусу:

“Гой еси, ласковой асударь Владимер-князь!

Что у тебя за болван сидит?

Что за дурак неотесоной?

Нечестно за столом сидит,

Нечестно хлеба с солью ест:

По целой ковриге за щеку мечит

И целу лебёдушку вдруг проглотил.

У моево сударя-батюшка,

Федора попа ростовского,

Была коровишша старая,

Насилу по двору таскалася,

Забилася на поварню к поварам,

Выпила чан браги пресныя,

От того она лопнула, -

Взял за хвост, под гору махнул.

От меня Тугарину то же будет!"
Or look at my dear soul,

At the young Tugarin Zmeevich!"

Taking the white swan

He had swallowed it at once

And also the big monastic bread.

Then says Alyosha from the entresol pole ${ }^{12}$

“Oh my dear kind lord, you prince Vladimir!

What a blockhead you have for a guest?

What an unpolished fool!

His sitting at the table is not honest

His eating of the bread-salt is not honest

A whole loaf he puts behind his cheek

And a whole swan he swallowed at once.

My own dear father

Fedor, the priest of Rostov,

Had a big old cow

She could hardly move around the yard

Once she came to the kitchen to the cooks

She draught a tub of unlevened wash

And that's why she had burst -

I've got her by the tail and thrown down the slope.

To Tugarin, I will do the same!"

(DN \& AP: № 43)

Tugarin's behaviour is set against Alyosha's modesty and adherence to proper conduct. Our attention is attracted to four main points: 
a) Tying his horse to the horse-pole, Alyosha uses a copper ring (not a silver ring or a golden one). Tugarin's behavior here is not described.

b) Alyosha crosses himself when entering the house, bows to the Prince and Princess. Tugarin does not make any signs of courtesy.

c) The Prince offers Alyosha the best places or a place he may choose himself. Alyosha chooses the most humble place (on the entresol pole, behind or on the stove). ${ }^{12}$ Tugarin takes the best place without invitation.

d) Tugarin eats everything as a whole, without carving or stopping for a break. Alyosha eats moderately and/or shares the food with his manservant.

Some scholars believe that the first feature, the horse-pole, is borrowed from a Turkic epic. In some versions Tugarin does not tie his horse at all (DN \& AP: № 37) - obviously, because the animal is special.

The enemy, or the stranger, does not know how to behave because he is a stranger. Tugarin takes someone else's place and sits down without invitation in a place of honour. His behaviour is impudent, he openly caresses Prince Vladimir's wife; in fact, he is often described as her lover (see below). The polite greeting and traditional bows before icons set Alyosha out emphatically as a Christian, but the point here is not his religion as such, but such oppositions, as the native $v s$. the foreigner, the civilised $v s$. the barbaric state, etc.

\section{The bylina about II'ya of Murom and the Great Idol}

Modern scholars believe that the story of Alyosha and Tugarin was eventually superseded by a story of Il'ya and the Great Idol. This tale is much better known: it was recorded more than 130 times (DN \& AP: 400).

The name of the hero's antagonist in this tale - the Great Idol (Russ. Idolische) is obscure. Some believe that this story is based on the murder of the Polovetz Khan's ambassador, named Itlar, in 1095 (Rybakov 1963: 109-110). Other scholars consider this name as an epitome for an unfriendly,

\footnotetext{
${ }^{12}$ In the traditional Russian house people may lie and sleep on the stove (but in the case of a prince's palace this is, of course, very unlikely). The meaning ascribed to this place was the same as in the case of the entresol pole.

${ }^{13}$ We have to explain in some detail what the entresol pole (Russ. polatnyj brus) is. The entresol (Russ. полати) was a raised platform in a Russian house. The platform was normally situated beside the stove or over the doors. The flooring of this platform rested on the entresol pole. Normally the entresol was used as a sleeping-room. The entresol was not an honorable place because it was usually associated with children or the elderly and lazy people who used to spend a lot of time there. For a short illustrated discussion of medieval and traditional house planning in Russia with special reference to towns see Rabinovich 1988.
} 
non-Christian stranger (Kondrat'yeva 1967: 90). B. Sokolov's theory (Sokolov 1916) has also enjoyed considerable popularity. According to Sokolov, the Great Idol was a real idol and the tale is based on a Christian satire on idolatry and the legend of a saint's combat against the devotees of a pagan religion. This idea seems plausible because, firstly, the life in question is the life of Saint Avraamij (Abraham) of Rostov - Alyosha's traditional birthplace. Secondly, Il'ya meets with the Idol in disguise as the hero had exchanged his clothes with a wandering pilgrim. Before destroying the idol, the saint had exchanged his clothes with a pilgrim, who proved himself to be St. John the Evangelist. In the bylina, the pilgrim who gave his robe to Il'ya is called "Ivan (i.e. John) the great elder" (Russ. starchische Ivanische). But it is hard to determine if the Life influenced the tale or vice versa (including the disguise motif). The existing vitae of the saint are late (fifteenth-seventeenth centuries) and extremely fictitious; it is not even known when exactly the saint lived.

Anumber of features in this tale suggest copying of, or at least borrowing from the story of Alyosha and Tugarin. For example, Il'ya, mocking the Idol's voracity, mentions the "priest of Rostov", who is always Alyosha's father. But here the Princess's affair with the stranger is totally absent.

B. Sokolov believes that we are dealing with three independent stories: Alyosha's departure, Alyosha and the great Idol, Alyosha and Tugarin. The rider on a flying horse has little in common with a huge, voracious and clumsy intruder in the feasting hall, and they have to be different characters (Sokolov 1916).

We shall quote the A.V. Markov record of this bylina as an example (Selivanov 1988: 154):

Говорит-то тут Идолище, выспрашиват:

“По многу ли есть хлеба Илья Муромец?"

Говорит-то калика перехожая: Thus said the wandering pilgrim:

Он ведь кушает хлеба по единому.

По единому-едному он по ломтю к выти".
The Great Idol speaks and asks questions:

"How many breads does Il’ya eat?"

"He eats bread one by one

One by one slice at a meal". 
“Он по много ли ведь пьет да пива пьяного?"

“Он пьет пива пьяного всего один пивной стакан”.

Рассмехнулся тут Идолище поганое:

“Почему этим Ильёю на Руси-то хвастают?

На долонь его положу, я другой прижму:

Останется меж руками да одно мокро".

Говорит-то тут калика перехожая:

“Ты по многу ли, царь, пьёшь и ешь, кушаешь?"

“Я чарочку пью пива полтора ведра, Я все кушаю хлеба по семи пудов,

Я мяса-та ем - к выти быка я съем”.

Говорит-то на те речи Илья Муромец, Il'ya answered those words thus:

“У моего у батюшки родимого

"My own dear father

Там была-то корова обжорчива,

Она много пила да много ела тут, -

У ей скоро ведь брюшина треснула". And her belly soon burst”.

\section{The main course at a feast and its misuse: why the swan was eventually left uncarved?}

The oldest version of the bylina, recorded in the seventeenth century, puts the emphasis on the swan as a significant, perhaps the main course:

И приходит день к вечеру, а уже идет пир на вечере, подадут еству девятую лебят белою (Astakhova 1960: № 27).

The day comes to the evening, the feasting continues and they serve the ninth meal - the white swan.

"How many inebriating beer does he drink?"

"He takes only one glass".

"Why are they boasting about this I'll put him on one of my palms and press him with another

There'll only rest a wet spot between my palms".

Then says the wandering pilgrim

And you the King, how much do you

I think, you are drinking and eating and always consuming?'

"My cup is a tub and a half

Seven stones of bread I eat

Had one voracious cow

She used to drink and eat much 
Other bylinas also single out the swan as the first, the last or otherwise significantly numbered course, e.g. the third (Markov 1904: 16). The invitation to the prince's feast included the formula "to eat the bread and to cut the white swan". In everyday life the swan's flesh was actually taboo, but for the prince's feast an exception was made; this emphasises the sacred meaning of this meal (Lipets 1969: 224).

The hostess offers an excuse for not cutting the swan: she was contemplating the guest's beauty. This is, as many scholars believe, a borrowing from another story, of a hero named Churila (Cyril), who was famous for his exquisite beauty (DN\&AP: 405). After studying this motive, A. N. Veselovsky (Veselovsky 1884: 97-100) suggested that this is a borrowing from an apocryphal story of Josef and his mistress. Nevertheless, this motif had its lawful place in this particular narrative, explaining the important fact of why the swan was not carved. One explanation is that the aggressive foreigner scares the prince and princess into submission. There is another explanation: Tugarin is the princess's lover. This situation is quite understandable, because Tugarin has many of late traits of the fiery Snake-Seducer of the Slavonic folklore (Khalanskij 1885: 167-176). However, some variants represent this as an accident (e.g. Grig. III 30 (334): 23-25).

Tugarin swallows the swan, pinning it on his own knife, which means that he could cut the bird if he wanted to (DN \& AP: № 35). Normally, he was supposed to share the swan and especially the wine with the other guests, or, more exactly, to order his manservant to pass it around like Alyosha does in a number of versions (Shub 1956: 213; Astakhova 1960: № 27).

The failure to carve the food properly means in both cases (Russian and Irish), the disruption of the established social relationships, and the misuse of the uncarved food (swallowing, gluttony) is represented as a statement on the relative status of the adversaries. But it is appreciated differently depending on which side of the conflict the glutton stands on.

As we have seen, Alyosha and Tugarin are depicted as members of two different social groups. Tugarin is a stranger in the society which Alyosha comes from. The story of Il'ya and the Great Idol goes further in describing how huge and voracious the Idol was. ${ }^{14} \mathrm{He}$ proudly describes himself:

Как я-то ещё ведь Идолище

А росту две сажени печатныих,

\footnotetext{
${ }^{14}$ For a collection of such descriptions, see Skaftymov 1994: 129.
} 
А в ширину-то сажень была печатная, Головище у меня да что люто лоханище, Глазища у меня да что пивные чащища, Нос-от ведь на роже с локоть был. (Selivanov 1988: 160)

Moreover, indeed, me, the Great Idol, I am two "sealed" sazhens in height ${ }^{15}$, And one sazhen in width,

My head is like a freaking huge tub, My eyes are like huge beer cups,

My nose is a cubit long.

It is worth noting that in Irish sources the situation is often reversed: the hugeness of a character does not feel like a negative trait. For example, the distance between Fergus's eyes is seven fists (OIr. dorn), and the distance between the Idol's eyes is also seven spans (Russ. piad'). According to Y. I. Smirnov (Smirnov 1971: 112-113; Smirnov 1974: 64-65), such descriptions of the main hero are quite rare in Slavic epic traditions. Perhaps, L. N. Majkov was more accurate: he adduces a number of examples where the heroes themselves are endowed with an extremely heavy step, an ability to sleep unusually long and to drink an unusual amount of wine. But describing the heroes and their adversaries, "the bylinas always keep in mind the contrast between the heroes, who are still common people, and the monstrous giants" (my translation, based on Majkov 1863: 98-100).

Scholars working in the field of the Slavic epic tend to separate stories of conflicts between "monoethnical" and "polyethnical" adversaries. L. A. Astaf'yeva (Astaf'yeva 1993: 5-7, partly basing on Putilov 1988: 45-54), singles out six main groups of plot types. Type 2 (rivalry of heroes, boasts are subjected to a test) envisages the "rivalry and contests of the monoethnical heroes". It is to be separated from Type 5 (struggle with the enemies). Putilov notes: "In the bylinas the contests take place, as a rule, inside of 'our own' world, but at the same time there could be traces of a typologically older conflict between the 'locals' and 'outsiders"' (my translation, based on Putilov 1988: 85). The "monoethnical" conflicts may include the conflicts between people from different cities and territories, a people belonging to different political and social groups (Astaf'yeva 1993: 73).

\footnotetext{
${ }_{15}$ Sazhen' is normally $2.13 \mathrm{~m}$, but this term could encompass other measures. A sealed sazhen is a measure approved by the State, an etalon with an official seal.
} 
The feast takes an important place in the conflicts inside the same community or, at any rate, in the relationships of the communities included in the same network of material and cultural exchange. It serves as a means of evaluating the relative standing of those groups or tribes. A good example is provided by P. Radin, the author of the well-known Trickster, a book dedicated to the trickster in the myths and traditions of the Winnebago Indians. Speaking of the trickster's gluttony, Radin notes that in the everyday life of the Winnebago gluttony is absolutely not tolerated; it becomes admissible only in the case of an eating contest at a ritual feast.

The 'winter feast' or the feast of the warrior's bundle was, according to Radin, originally a prayer for success in war; it then becomes a general prayer for the well-being of the tribe (Radin 1970: 157, 379). The meat was carved following strict rules and there also was a 'hero's portion': the head of a deer. Before eating the 'hero's portion', an eating contest took place. Two warriors from the two phratries of the tribe (Thunderbird and Bear) participated in the contest. The first man, who had finished eating, was considered the best warrior. Radin notes that the winner would always come from the phratry which organised the feast (Radin 1970: 382). It is interesting to note that the one who had to set up the feast was not supposed to eat himself at all - he should provide music and entertainment.

Not only the right to carve the main course, the important or sacred meal, but also the gluttony, the fast engorging of food on such communal feast, could serve as a proof of valour, and not only for a single warrior, but also for a phratry or tribe. In $S M M D$, Conall Cernach's wild devouring of almost the whole pig is nowhere condemned. On the contrary, it is described as an exploit and was regarded as a great achievement, as, for example, in the tale "Tidings of Conchobar son of Ness" (ed. Stokes 1910: 28-9):

Though there was no bravery there save Conall Cernach son of Amergen the Dark-haired, it would be enough for contention - that is, from the hour he took a spear in hand he was never without slaying one of the Connaughtmen every day, and without destroying (their houses) by fire every night. And he never slept without a Connaughtman's head under his knee. There was not in Ireland a cow-chief's land on which Conall Cernach had not wrought someone's slaughter. 'Tis this Conall Cernach that divided Mac-dá-thó's pig as a trophy of valour in front of the champions of the men of Ireland.

The Connachta-Ulaid relationship may be described as a "monoethnic" one. Both sides are speaking the same language; there is nothing specific, 
foreign or monstrous about their looks, clothes and conduct (at least, in terms of the society here described). ${ }^{16}$ The "monstrous" behaviour(swallowing of the Pig) is ascribed to one from "our" side. Nevertheless, the strife on account of Mac Dathó's Pig attains such a scale that in consequence the monoethnicity is broken; the Ulaid and Connachta separate. It escalates into a major strife because the feast is not regulated: the participants are equal and the host totally absconds from regulating the feast because of his inferiority. The end title of the story in the Edinburgh MS runs:

Conad i iomsgaradh Conacht, Ulltach mun gcoin , mun mhuic go ninge,

This is the separation of the Connachta and Ulstermen on the account of the dog and the pig so far (Watson 1928: 222).

In the Russian story the point of departure is the same: guests at a nonregulated feast. But here the adversaries are not monoethnic (in this case the term "ethnic adversary" is used). They appear in the shape of a clumsy and voracious giant (the Idol) or of a lustful demon on a flying horse. They do not know and do not wish to know anything about the rules of the society they are intruding on. In many versions the Idol tries to prevent people from praying and especially from giving alms (this is sometimes given as a reason why he wishes to interview the wandering pilgrim - Il'ya in disguise).

This forceful exclusion of the enemy from the world of social relationship in the Slavic epic would often be explained by political circumstances - the strife of Russians with nomads and southern Slavs with Turks. It is worth noting that in the Ossetian epic the same tendency may be traced. A number of adversaries here bear Turkic names; some of them could be traced to real historical characters (Gur'yev 1971). And the outcome of the stories is quite the opposite. In the Irish story it is a tragic and bloody separation of the two related tribes, the event that would eventually lead to even more fatal consequences. In the Russian story the ending is happy: the enemy is killed and the order is restored. Alyosha bitterly denounces the behaviour of the princess, and in a couple of variants she may even be executed.

\section{Conclusion}

The scope of this article is necessarily very limited. It has been necessary to leave out comparisons with other Indo-European traditions for the most part and also some theoretical points. However, the comparison of these

\footnotetext{
${ }^{16}$ On the traditional formulas describing the ethnic adversary, see Smirnov 1974.
} 
two descriptions of a quarrel over the meat of a sacred animal may be useful. Both stories see the feast as a place where the relative social standing of people and groups can be (re-)evaluated. Gluttony, be it viewed in a positive or negative manner, is represented as a vehicle for asserting status. In both cases also a non-regulated feast is regarded as a foreboding of danger and destruction.

Moscow State University

\section{Abbreviations}

BPK - Bylinas of the Pudozhsky Region (= Byliny Pudozhskogo kraya. Podg. tekstov, stat'ya i primechaniya G.N. Parilovoj i A.D. Sojmonova. Predisl. i red. A.M. Astakhovoj) Petrozavodsk, 1941.

BS - Bylinas of the North (= Byliny Severa. Zapisi, vstupit. stat'ya i commentarii A.M. Astakhovoj) vols. 1-2. Moscow - Leningrad, 1938-1951.

DN \& AP - Smirnov, Iu. I., \& Smolitskij, V.G., eds., 1974, Dobrynya Nikitich i Alyosha Popovich. Moscow.

FB - Windisch, E., ed., 1880, 'Das Fest des Bricriu', in Irische Texte I. Leipzig, 235-311

G. - Nikiforov, A.I., 1949-1951, Bylinas of Onega written down by A.F. Gilferding in the summer of 1871 (= Onezhskiye byliny, zapisanniye A.F. Gil'ferdingom letom 1871 goda. Podg. teksta i komm.) vols. 1-3. Moscow.

Grig. - Grigoriev, A. D., ed., 1904, 1939, 1940, Bylinas and Historical Songs of Archangelsk (= Arkhangel'skiye byliny $i$ istoricheskiye pesni, sobranniye A.D. Grignor'evym v 1899-1901 gg.) vol. I. Moscow, 1904; vol. II, Prague, 1939; Vol. III, St. Petersburg 1910.

R. - Putilov, B. N., ed., 1989, Songs collected by Rybnikov (= Pesni, sobranniye P.N. Rybnikovym. Pod red. B.N. Putilova), vols. 1-3. Petrozavodsk.

Tikh.-Mill. - Russkiye byliny staroj i novoj zapisi. Pod red. N.S. Tikhonravova, V.F. Millera. M., 1894.

ZhMNP - Zhurnal ministerstva narodnogo prosvescheniya. 


\title{
SUMMARY \\ НИНА ЧЕХОНАДСКАЯ
}

\author{
НЕРАЗРЕЗАННЫЙ ЛЕБЕДЬ: \\ РУССКИЕ И ИРЛАНДСКИЕ ГЕРОИ НА ПИРУ
}

В СТАТЬЕ ПР ОВОДИТСЯ СРАВНЕНИЕ МЕЖДУ ИРЛАНДСКИМИ САГАМИ, ЦЕНТР АЛЬНОЙ ТЕМОЙ КОТОРЫХ ЯВЛЯЕТСЯ ПИР - «ПИР БРИКРЕНА» И «ПОВЕСТЬ О СВИНЬЕ МАК ДАТО» - И РУССКИМИ БЫЛИНАМИ, В ЧАСТНОСТИ, БЫЛИНОЙ ОБ АЛЁШЕ ПОПОВИЧЕ И ТУГАРИНЕ ЗМЕЕВИЧЕ И ОБ ИЛЬЕ МУРОМЦЕ И ИДОЛИЩЕ. И В «ПовеСТИ О СВИНЬЕ МАК ДАТО», И В БЫЛИНЕ ОБ АЛЁШЕ ПОПОВИЧЕ ГЛАВНОЕ БЛЮДО НА ПИРУ ОСТАЁТСЯ НЕРАЗРЕЗАННЫМ, А ОДИН ИЗ ГОСТЕЙ ПРОГЛАТЫВАЕТ ЕГО ЦЕЛИКОМ. НО ЕСЛИ В РУССКИХ БЫЛИНАХ В РОЛИ «ОБЖОРЫ» ВЫСТУПАЕТ ВРАГ, «ЭТНИЧЕСКИЙ ПРОТИВНИК» (ПО Б. Н. ПутИЛОВУ), ТО В ИРЛАНДСКОМ ЭПОСЕ ЭТО ОДИН ИЗ ИРЛАНДЦЕВ. ДРЕВНЕИРЛАНДСКИЕ ГЕРОИ ФАКТИЧЕСКИ ПРИНАДЛЕЖАТ К ОДНОМУ ЭПИЧЕСКОМУ СОЦИУМУ, НО К РАЗНЫМ ЕГО ЧАСТЯМ (УЛАДЫ И КОННАХТЫ). РАЗР ЕЗАНИЕ СВЯЩЕННОГО ЖИВОТНОГО И Р АСПРЕДЕЛЕНИЕ КУСКОВ БЫЛО СРЕДСТВОМ УПОР ЯДОЧИВАНИЯ КАК ВНУТРИСОЦИАЛЬНЫХ, ТАК И МЕЖПЛЕМЕННЫХ ОТНОШЕНИЙ (КАК ПОКАЗЫВАЕТ Р ЯД ПРИМЕРОВ ИЗ ДРУГИХ ТР АДИЦИЙ, В ТОМ ЧИСЛЕ ИНДЕЙЦЕВ ВИННЕБ АГО, ОПИСАННОЙ П. РАДИНЫМ). В ОБОИХ СЛУЧАЯХ ПИР СЛУЖИТ СРЕДСТВОМ УТВЕР ЖДЕНИЯ СТАТУСА ВНУТР И СОБ СТВЕННОГО СОЦИУМА, ОБЖОР СТВО (ПОЖИР АНИЕ ЦЕЛОЙ СВИНЬИ, БЫКА, ЛЕБЕДЯ) - СПОСОБ ОМ ДОКАЗАТЬ СВОЁ ПР ЕВОСХОДСТВО. ЕСЛИ В РУССКИХ БЫЛИНАХ ОБЖОРСТВО ТУГАРИНА (ИДОЛИЩА) ПРИВОДИТ В КОНЕЧНОМ СЧЁТЕ К ЕГО УНИЧТОЖЕНИЮ, ТО В ИРЛАНДСКИХ САГАХ НАРУШЕНИЕ ЭТИКЕТА НА ПИРУ ВЕДЁТ К РАСКОЛУ МЕЖДУ ДВУМЯ ПЛЕМЕНАМИ И ПРЕВРАЩЕНИЮ КОННАХТОВ И УЛАДОВ В ЭТНИЧЕСКИХ ПРОТИВНИКОВ. В ОБОИХ СЛУЧАЯХ НЕРЕГУЛИРУЕМЫЙ ПИР (НА КОТОРОМ НЕТ ОБЩЕПРИЗНАННОГО ХОЗЯИНА/РАСПОР ЯДИТЕЛЯ, КОТОРЫЙ БЫ ЗАНИМАЛСЯ Р АСПРЕДЕЛЕНИЕМ ПИЩИ) ВЕДЁТ К КОНФЛИКТУ. 